Сур'як Алла, кандидат економічних наук, доцент, Східноєвропейський національний університет імені Лесі Українки, кафедра аналітичної економіки та природокористування, м. Луцьк, ORCID ID 0000-0002-3094-9941, e-mail: avsuriak@gmail.com

https://doi.org/10.29038/2411-4014-2020-01-137-145

\title{
ІННОВАЦІЙНЕ СПОЖИВАННЯ ЯК СУЧАСНА ЕКОНОМІЧНА ПОВЕДІНКА СПОЖИВАЧА
}

У статті розглядається інноваційне споживання як сучасна економічна поведінка споживача через визначення сутності інноваційного споживання, ролі в оновленні споживання мотивації сучасного споживача товарів та послуг.Охарактеризованоосновні складові інноваційного споживання в економічній поведінці споживача, шляхи рівноваги інноваційних процесів у виробництві та споживанні, забезпеченні необхідного обсягу платоспроможного попиту на інновації та інноваційні продукти які досягаються інноваційним споживанням.Обгрунтовано шляхи оновлення сприйняття споживачами інновацій та інноваційних продуктів, запропоновано шляхи формування інноваційного споживання в економічній поведінці споживача.

Ключові слова: інноваційне споживання, мотивація споживання,оновлення мотивації споживача, економічна поведінка споживача, економічна поведінка споживача інноваційних товарів та послуг.

Сурьяк Алла, кандидат экономических наук, доцент, Восточноевропейский национальный университет имени Леси Украинки, кафедра аналитической экономики и природопользования, г. Луцк

\section{ИННОВАЦИОННОЕ ПОТРЕБЛЕНИЕ КАК СОВРЕМЕННОЕ ЭКОНОМИЧЕСКОЕ ПОВЕДЕНИЕ}

В статье рассматривается инновационное потребление как современное экономическое поведение потребителя через определение сущности инновационного потребления, роли обновлении потребления мотивации современного потребителя товаров и услуг. Охарактеризировано основные составляющие инновационного потребления в экономическом поведении потребителя, пути равновесия инновационных процессов в производстве и потреблении, обеспечении необходимого объема платежеспособного спроса на инновации и инновационные продукты который достигается инновационным потреблением. Обосновано пути обновления восприятия потребителями инноваций и инновационных продуктов, предложено пути формирования инновационного потребления в экономическом поведении потребителя.

Ключевые слова: инновационное потребление, мотивация потребления, обновление мотивации потребителя, экономическое поведение потребителя, экономическое поведение потребителя инновационных товаров и услуг.

\section{Alla Suriak, \\ Ph.D. in Economics, Associate Professor, Lesya Ukrainka Eastern Europen National University, Department of Analytical Economics and Natural Resources Management, \\ Lutsk}

\section{THE INNOVATIVE CONSUMPTION AS A MODERN ECONOMIC BEHAVIOR}

The article considers the innovative consumption as the modern consumer's economic behavior being viewed herein through the essence of its definition, as well as through the motivation character of the modern consumer of goods and services within the consumption updating. Moreover, the innovative consumption is a challenge of the modern world, as well as the conscious and responsible demand generation, the guarantee of the environmentally and 
friendly maintenance of the production and resource use, and the assistance in the alternative promising ways for the efficient production and responsible profitability.

The motivation of consumer's innovations is a set of needs and motives encouraging consumers to active activities towards the innovative renewal of their behavior based on scientific and technological progress and the use of innovations. It is reached through the purchase of innovative products and their use for the conscious and responsible consumption as the final phase of the social production and component of every business process.

The motivation is considered in the innovative consumption as the choice of methods and directions of operations of motive forces (motives). The last-mentioned are involved to achieve our goals and responsibility for all the previous manufacturers' and sellers' actions, their behavior on the market and the impact of the implementation of the goal on the further development of the scientific and technological progress, innovation and eco-friendly environment. The motivation of consumer innovations should be considered in two vectors: 1) the motivation to support the creation of production of innovations that meet the needs of modern demand and affordable sales of these innovations and 2) the motivation to understand these innovations, the conscious purchase and consumption of these innovations.

The innovative consumption is one of the important tools for creating a solvent demand for innovations. This leads economic entities, as the main collective consumers of innovations, to produce, to consume and to work with innovations. Moreover, they may demand and participate in the development of technology and high technologies, raising standards and quality of the life through a quantitative and qualitative change in the factors causing its growth, namely, a multiple increase in the share of products received from the innovation.

The following ways have been proposed for forming a balance of innovative processes in the production and consumption, ensuring the necessary volume of effective demand for innovations and innovative products:

1. The encouragement concerning the exchange of innovations and innovative products through the import of innovations and export of domestic innovations from other countries and in our country, to expand those who own new technologies or ideas for their production, creating conditions for increasing investment resources that will provide support for an effective domestic innovation investment process. The exchange of innovations and the results of using innovative products contributes to the establishment of innovative behavior of producers and consumers, maintaining solvent innovative demand.

2. The assurance of the accessibility and predictability of investment resources and their cost in the state, which will stimulate direct and indirect instruments to force institutions and organizations to resource- and energy-saving, environmentally friendly, modern high-tech technologies, as well as to the innovative management and organization of economic activity. The predicted value of investment and innovative resources will ensure the expected, efficient and responsible use of investment resources and increase innovative products.

3. The promotion of mechanisms: the economic behavior of producers and consumers as the innovative behavior, and the formation of sustainable innovative interests.

4. The assistance in the formation and implementation of the state innovation programs, national innovation projects, targeted innovation development programs of territorial communities.

5. The formation of the innovative demand in the form of consumption patterns of new, more advanced goods and services inherent in countries with developed market economies and growing consumer cultures.

6. The reorientation of the socio-economic activity of consumers at the micro level in order to increase or expand the consumption to increase the consumption of innovations and innovative products as a subject of innovative development for the development of the economy and society.

This will ensure the formation of the balanced innovative processes in the production and consumption, in their consistency and simultaneity, and will form the necessary volume of the solvent demand for the innovation and innovative products. The state assistance forms listed herein will become the basis for the formation of the necessary and sufficient volume of the solvent demand for innovations through the mechanisms of the investment and innovative behavior. That will be approved as a progressive, correct and mutually beneficial innovative development in the economy, ensuring the Ukrainian economy development as an innovative type of economy, not only by the growth of the investment, but also primarily innovation activity of economic entities.

Key words: innovative consumption, consumption motivation, consumer motivation updating, consumer's economic behavior, economic behavior of the consumer of innovative goods and services.

Постановка проблеми та іï значення.Оновлення мотивації споживання та впровадження інновацій у споживанні потребує глибокого усвідомлення для визначення змін існуючоїмотивації споживання, формування нової у всіх сучасних споживачів. Ці виклики виходять із особливостей сучасного господарювання, зміни умов формування економічної поведінки виробників та споживачів, зміни факторів виробництва, актуалізації природоохоронної діяльності та екологічної безпеки. 
Аналіз останніх досліджень і публікацій.Актуальність аналізу та глибокого теоретичного вивчення поведінки споживачів як елемента впливу на виробництво і управління інноваційною діяльністю виробника зумовила увагу до цієї проблеми багатьох вчених. Окремі теоретичні і методологічні аспекти даної проблеми досліджували та висвітлили у своїх працях Г. Армстронг, Е. Блекуел, В. Вонг, К. Гренроос, Д. Енджел, Ф. Котлер, Ж.-Ж. Ламбен, А. Маслоу, П. Мініард, Д. Сондерс. Е. Стігліц П. Холанд. Проблеми сприйняття споживачами інноваційної діяльності досліджували: Б. Амбале, Р. Піндайк, М. Портер, Б. Санто, Д. РубинфельдЙ. Шумпетер. Особливості поведінки споживача на ринку також визначили у своїх працях вчені української школи маркетингу: М. Бутко, В. Геєць, І. Гут, В. Захарченко, О. Зозульов, В. Ільчук, В. Кардаш, Л. Пан, , А. Старостіна, А. Федорченко, Л. Чернюк, О. Шафалюк, та інших. Деякі аспекти споживчої поведінки які враховують в своїй діяльності підприємства торгвілі визначено в працях багатьох вітчизняних вчених, серед яких Л. Балабанова, С. Бай, Б. Гинів, Л. Лігоненко, А. Мазаракі, В.Марцин, Н. Новальська, Н. Ушакова та ін.

Однак, багато питань, щодо інноваційних змін поведінки споживача в сучасних умовах розвитку ринку які мають враховуватись у стратегічному управлінні виробництвом, залишаються недостатньо вирішеними.

Мета і завдання статті. Саме тому метою статті $є$ визначення сутності інноваційного споживання, особливості інноваційної поведінки споживача, мотивів поведінки споживачів у виборі інвестиційних товарів та послуг та шляхи комплексного використання характеристик інноваційного споживання для оновлення економічної поведінки споживача,покращення отриманих результатів, формування виробничої стратегії для підвищення результативності та ефективності діяльності суб'єктів економіки

Викладення основного матеріалу та обгрунтування отриманих результатів дослідження.

Інноваційне споживання є викликом сучасного світу, свідомим та відповідальним формуванням попиту та запорукою збереження екобезпечного виробництва та використання ресурсів, допомогою у виборі перспективних шляхів результативного виробництва та відповідальної прибутковості.

Якщо розглядати мотиваціюяк сукупність потреб, зовнішніх і внутрішніх спонукань до системи дій та вчинків, що ми називаємо мотивами, то оновлення мотивації відбувається постійно. Мотивація змінює активну діяльність у певному напрямку під впливом більше зовнішніх, а не внутрішніх спонукань і не тому що внутрішні спонукання не сформувались чи не проявились, а тому що зовнішні впливи $є$ більш активними. Зовнішні для людини чинники їх споживання формують виробники при виробництві товару, маркетологи при просуванні цього продукту на ринок. Практики використовують досягнення всієї сучасної науки, при чому, не тільки економічної, але і багатьох інших.Тому і споживачу потрібно постійно оновлювати своє споживання на всіх стадіях його планування, формування, реалізації, контролю,

Мотивація інновацій споживача - це сукупність потреб і мотивів, які спонукають споживача до активної діяльності в напрямку інноваційного оновлення своєї поведінки на основі науковотехнічного прогресу та використання інновації. а також шляхом покупки інноваційних продуктів та їх використання для свідомого та відповідального споживання як кінцевої фази суспільного виробництва та складової кожного господарського процесу.

У інноваційному споживанні мотивація розглядається нами як вибір методів та напрямів дії спонукальних сил (мотивів) длядосягнення своєї мети та відповідальності за всі попередні дії виробника та продавця , їх поведінки на ринку та впливу реалізації поставленої мети на подальший розвиток науково -технічного прогресу, інновацій та екобезпечного середовища. Мотивацію інновацій споживачатреба розглядати в двох векторах: 1) мотивація до підтримки створення виробництвом інновацій, які відповідають запитам сучасного попиту та доступного продажу цих інновацій та 2) мотивація до розуміння цих інновацій, свідома купівля і споживання цих інновацій.

Сприйняття інновацій споживачами в сучасних умовах цікавить більше виробників ніж споживачів [1]. Виробники та продавці основою для формування попиту і збільшення обсягу продажів вбачають у найбільш повному та всебічному знанні споживача, його цілей, намірів, смаків та уподобань, доходів та їх розподілу,економічної поведінки, потреб та їх зміни, мотивацій до покупки, поінформованості та реакції на інновації. 
Практика вивчення споживачав першу чергу зосереджується на дослідженні потреб споживача та його очікуваннях, запитах і аналізі ступеня задоволеності споживача. Для максимального задоволення вимог споживача проводять дослідження факторів впливу на ступінь задоволеності потреб споживача як важливого та визначального суб'єкта ринку та споживача інновацій. Цими факторами визнано: 1) рівень доходу споживача; 2) належність до певної групи покупців (оптові та роздрібні покупці, посередники, організації- споживачі, споживачі сировини, матеріалів, обладнання, кінцеві користувачі та ін.); 3) рівень обізнаності та інформованості споживача; 4) можливості отримання найбільш повної інформації про фірму, особливості іiі виробництва, використання ресурсів, відповідність стандартам та особливо міжнародним стандартам і головне, якостейпродукту; 5) тип поведінки споживача (консерватори, помірні, новатори i авангардисти); 6) досвід задоволеності минулими покупками у даного чи інших виробників; 7) тип реакції сприйняття нового продукту (первинне впізнавання, ідентифікація, співвідношення зі своїми потребами і можливостями, негативне ставлення чи негативний попередній досвід та ін.).

Сучасна практика інноваційного веден6ня бізнесу розглядає процес прийняття нового товару споживачем як цілісний процес, який складається з таких послідовних етапів.

1. Первинна поінформованість споживачаякий дізнається про інновації чи інноваційний продукт, але не має достатньо інформації.

2. Пізнавання товару споживачем який вже має певну інформацію, сформував для себе цікавість до нового продукту; можливий пошук додаткової інформації про інновацію (реклама, проспекти, довідники).

3. Ідентифікація нового товару, який споживач зіставляє зі своїми потребами.

4. Оцінка споживачем можливостей використання інновації та прийняття ним рішення про купівлю тавикористання нововведення.

5. Апробація інновації споживачем з метою отримання більш точних відомостей про інновації та про можливість придбання.

6. Прийняття рішення за результатами апробації про придбання або інвестуванні в створення інноваційного продукту.

Крім етапів сприйняття нового товару маркетологистараються класифікувати споживачів за ступенем їх сприйнятливості інновацій. Визначено, що, у більшості споживачів існує психологічний поріг для сприйняття та використання інновацій. Та тверде переконання, що після ефективних рекламних і маркетингових заходів співвідношення між тими, які готові сприйняти і не сприйняти інновації змінюється, а саме, число перших неухильно зростає.

Практика також вказує на те що особливість та характер інновації позначається на темпах іiі сприйняття [2]. Деякі види інновацій отримують прихильність споживачів та популярність миттєво, a іншим для цього потрібен тривалий час та поступовий прогрес у сприйнятті. Інноваційна сприйнятливість і темпи сприйняття та прийняття інновації залежать від різноманітних економічних, економіко-організаційних, психологічних, соціальних, соціально-економічних,науково-технічних таорганізаційно-технічних факторів.

Серед основних вимог споживача до загальних властивостей, необхідних для інноваційних продуктів та послуг, є ціна інноваційного продукту, споживчі властивості, конкретні показники якості, енергоємність, конструкторські характеристики, експлуатаційні можливості, дизайн, комфортність, упакування .

Зокрема, розгляд та оцінка загальних властивостей інноваційного продукту відбувається за такими напрямками:

- переваги над існуючими товарами чи послугами. Наприклад, чим кращі технічні характеристики продукту. тим швидше вінзнайде свого споживача і тим швидшим буде сприйняття інновації виробництва споживачами.

- наступність і сумісність методів вибору споживачем інноваційного продукту, тобто відповідність прийнятим споживчим поведінковим моделям та досвіду споживачів інновації. Так, більший успіх буде у інноваційного продукту який не потребує інноваційного застосування , $\epsilon$ не новим для психології та звичок споживачів, усталеної процедури використання і дає можливість мінімізувати психологічний стрес при використанні інноваційного продукту; 
- складність, або нечіткість розуміння сутнісних особливостей інноваційного продукту чи послуги, принципів їі використання чи впровадження, а також переваг використання цього нового продукту для задоволення вже існуючих потреб споживача.

- поступовість, структурованість та подільність процесу використання інновації, тобто можливість поступового та поетапного використанняінноваційного продукту та поступової оцінки результатів використання;

- зрозумілість, відчутність та наочність вигоди та відповідності особистим запитам споживача, тобто можливість чітковиразити корисність і вигоду від застосування інновації;

-матеріальна оцінка інновації та результатів використання інновації, тобто, корисність для споживача інновації, яка може бути виражена кількісно (матеріально), часто видається на перший погляд більш привабливішою, ніж інновації, спрямовані на якісне удосконалення та покращення життя, господарювання. та функціонування системи в цілому, хоча на практиці об'єктивна та суб'єктивна корисність інноваційних продуктів може мати не тільки прямий вплив на матеріальні вигоди а й значнікомплексні матеріальні та нематеріальні вигоди та ефекти.

Виходячи з такого бачення оцінки споживачем інноваційного продукту та його аналізу кожного продукту, що містить інновації і шукає свого споживача то можемо зробити висновок що для забезпечення необхідного і достатнього рівня сприйняття споживачем інновацій потрібне створення умов, які будуть забезпечувати формування платоспроможного попиту на інноваційні продукти та послуги, і досягнення зростаючого рівня розвитку інноваційної сфери для формування інноваційноінвестиційного процесу, що забезпечує безперервну генерацію інновацій і здатного задовольнити попит на інновації буде правильними.

Однак врахування змін самого споживача, його унікальності, бажання до удосконалення використання власних обмежених та необмежених ресурсів для максимізації ефективності, максимізації корисності, збереження та покращення фізичних можливостей, бачення себе не тільки як споживача, але й водночас як учасника виробництва цих товарів та послуг відповідального за наслідки споживання цих інноваційних продуктів самому, іншими споживачами, впливу на екологію та довкілля, забезпеченість ресурсами майбутні покоління сприяє розгляду інноваційного споживання як комплексного явища і складової інноваційно-інвестиційних процесів в економіці, суспільстві,світі [3].

Тому, не виробники чи продавці мають організовувати зміни попиту на інновації та споживання інноваційного продукту [4].А саме споживачі мають вимагати від себе в першу чергу, а вже потім від виробників та держави необхідного рівня розвитку інноваційної сфери[5].Держава та ії інституційні можливості зміни споживання та споживання інноваційного продукту відносяться до сфери державного стратегічного управління, планування і прогнозування на відповідних рівнях економіки, створення системних умов для випереджального розвитку інноваційної сфери; формування необхідного рівня компетенцій, знань та вміньдля підготовки достатньої кількості та якості інноваційного управління, зростання освітнього рівня населення в цілому; підвищення інноваційної управлінської культури суб'єктів економіки на всіх рівнях господарювання.

Оновлення сприйняття споживачами інновацій та інноваційних продуктів, формування інноваційного споживання можливе через:

1. Підвищення поінформованості існуючих та потенційних споживачів інноваційних продуктів про наявність інновацій. Це може відбуватися через забезпечення дієвого державного регулювання доступу до інформації в першу чергу фахівців, які мають теоретичні знання та результати наукових досліджень, можуть запропонувати практичні рекомендації про шляхи розширення знання як для індивідуальних так і колективних споживачів інновацій позитивних та негативних впливів та наслідків для споживачів інновацій, суспільного виробництва, використання обмежених та невідновлюваних ресурсів, екології та природокористування, забруднення навколишнього середовища.

2. Підвищення рівня доходів споживачів які визначають їх економічну, а особливо споживчу поведінку [6]. Це можливе через зростання платоспроможного попиту в економіці, із забезпеченням можливістю підвищувати свою платоспроможність тих працівників, які володіють вміннями продукувати інновації та інноваційні продукти внаслідок задіяння у виробництві продуктів та послуг рівня їх освіти і творчих здібностей можливістю створити нові споживчі властивості, технічні, 
естетичні та соціальні цінності інноваційних продуктів, а також підвищувати запити інших споживачів, їх здатності сприймати, використовувати і працювати 3 інноваціями [7].По суті, підвищувати платоспроможний попит кваліфікованих інноваційно результативних працівників, які своєю працею створюючи інноваційні продукти сприяють розвитку попиту на інновації в споживачів та виробників

3. Підвищення рівня вимог до інноваційних продуктів, розширення запитів споживачів до рівня стандартів на продукти, послуги, технології.Це можливо через підвищення та дотримання стандартів управління, використання ресурсів, утилізації чи переробки відходів. впливу на життя населення політикою економічного та технічного регулювання, реалізації національних стандартів, які допоможуть суб'єктам економіки як основним колективним та індивідуальним споживачам інновацій та інвестиційних продуктів розширити споживання, змінити його комплектацію та компонування інноваціями [8].3 одного боку, стандартизація продукції унеможливлює інновації чи утруднює їх, а 3 іншого боку, стандартизація продукції сприяє появі нового в межах вимог, чітко визначених основних запитів споживачів до продукції та іiі безпеки. витрат виробництва та його результативності Крім того. стандартизація продукції в умовах конкуренції швидше формує попит на інновації у виробників які планують розширювати ринки збуту та збільшувати свою прибутковість. Це виникає тільки у випадку, якщо суб'єкт економіки вчасно зрозумів виклики сучасного господарювання де зміни запитів споживачів зумовлені змінами умов їх життя та діяльності, і виникає розуміння того, що без змін вони вже не зможуть продовжувати ефективно виконувати свої завдання, чи загалом існувати як виробник[9].

Отже, інноваційне споживання є одним з важливих інструментів формування платоспроможного попиту на інновації, що змушує суб'єктів економіки як основних колективних споживачів інноваційпродукувати, споживати і працювати 3 інноваціями, а також вимагати та брати участь у розвитку техніки і високих технологій, підвищення стандартів і якості життя через кількісну та якісну зміну факторів, які обумовлюють його ріст, а саме: багаторазове підвищення частки продукції, отриманої від інноваційної діяльності.

Такий рух на формування інноваційного споживання сприятиме зростанню культури споживання та забезпечить інноваційний тип розвитку формування рівноваги інноваційноінвестиційних процесів у виробництві та споживанні що має знаходити підтримку в державній та приватній соціально-економічної стратегії розвитку із забезпечувальною допомогою державного регулювання попиту споживачів та виробників на інновації, інноваційні продукти, інноваційні процеси [10]. Для формування рівноваги інноваційно-інвестиційних процесів у виробництві та споживанні, забезпеченні необхідного обсягу платоспроможного попиту на інновації та інноваційні продуктиварто запропонувати такішляхи:

1. Стимулювання обміну інноваціями та інноваційними продуктами через імпорт інновацій та експорт вітчизняних інновацій 3 інших країн та в нашу країну, для розширення тих хто володіє новими технологіями чи ідеями для їх виробництва, формування умов для збільшення інвестиційних ресурсів, які забезпечать підтримку ефективного вітчизняного інноваційно-інвестиційного процесу [11]. Обмін інноваціями та результатами використання інноваційних продуктів сприяє утвердженню інноваційної поведінки виробників та споживачів, підтримання платоспроможного інноваційного попиту.

2. Забезпечення доступності та прогнозованості вартості інвестиційних ресурсів в державі, яка буде стимулювати прямими та опосередкованими інструментами спрямуванняустанов та організацій на ресурсозберігаючі та енергозберігаючі, екологічно безпечні, сучасні наукомісткі технології, а також на інноваційні управління і організацію господарською діяльністю. Прогнозована вартість інвестиційних та інноваційних ресурсів забезпечить очікуване, результативне та відповідальне використання інвестиційних ресурсів та збільшення інноваційної продукції.

3. Сприяння формуванню механізмів: економічної поведінки виробників та споживачів як інноваційної поведінки, сприяти формуваннюстійкихінноваційних інтересів.

4.Забезпечення формування та реалізації державних інноваційних програм, національних інноваційних проектів, цільових програм інноваційного розвитку територіальних громад. 
5. Формування інноваційного попиту у вигляді моделейспоживання нових, більш досконалих товарів та послуг властивих країнам з розвинутою ринковою економікою та зростаючою споживчою культурою.

6. Переорієнтації соціально-економічної активності споживачів на мікрорівні з цілей збільшення чи розширення споживання назбільшення споживання інновацій та інноваційних продуктів як суб'єкта інноваційного розвитку для розвитку економіки та суспільства.

Такі шляхи формуванні рівноваги інноваційно-інвестиційних процесів у виробництві та споживанні у їх системності та одночасності сформують необхідний обсяг платоспроможного попиту на інновації та інноваційні продукти [12]. Перераховані форми державного сприяння стануть основою для формування необхідного і достатнього обсягу платоспроможного попиту на інновації через механізми інвестиційної та інноваційної поведінки утвердять як прогресивний, правильний та взаємовигіднийінноваційний розвиток в економіці забезпечать розвиток економіки України як економіки інноваційного типу, шляхом зростання не тільки інвестиційної, a, насамперед, інноваційної активності суб'єктів економіки.

Успіх інновацій виробника та продавця значно залежить від здатності споживача оновити свою економічну поведінку, яка сформує відповідне інноваційному виробництву інноваційне споживання [13].

Пропонуємо п'ять основних складових інноваційного споживання в економічній поведінці споживача:

1) оцінка відносної переваги нового продукту перед вже існуючими, які мають здатність задовольняти певні потреби і ці переваги забезпечені новими технологіями, є ресурсозберігаючими, енергоощадними, екологічно безпечними.

2) оцінка сумісності нового продукту з іншими продуктами та послугами, які доступні та використовуються споживачем, не потребує кардинальної зміни смаків та уподобань;

3) оцінку стимулювання новим продуктом який має новизну і деяку складність до формування нових знань, вмінь, навиків, створює потребу у підвищенні компетенцій та сприяє цілеспрямованому підвищенню професійності, технічної обізнаності, для можливості повноти та результативності використання інноваційного продукту;

4) оцінку можливості використання нового продукту для більш раціонального використання своїх ресурсів, збільшення ефективності власного господарювання, зменшення витрат в наступних періодах;

5) оцінкуздатності нового товарусприяти підвищенню конкурентоспроможності виробника діяльність якого здійснюється у відповідності до міжнародних стандартів виробництва, умов праці на їх підприємствах, природоохоронних заходах наповненні бюджету.

Інноваційне споживання в економічній поведінці споживача в першу чергу має оцінювати основні технічні та технологічні перевагиінноваційних товарів та послуг через:

1) розширення технічнихможливостей та можливостей роботи у відповідності до вимог часу, здатність відповідати сучасним технічним новаціям, бути конкурентоспроможним як виробник і як споживач, ;

2) можливість уникати чи мінімізувати моральне старіння у методах та моделях поведінки;

3) можливість мати своєчасну інформацію про громадської реакції та виражати свої реакції на товари та послуги ;

4) розширення можливостейвикористання технічних інновацій для запобігання різноманітного пошкодженням товарів та результатів праці..

5) можливість випробувати чи тестувати товар в стислі терміни, що збільшує можливості вибрати товар споживачем

6) доступність, опису переваг товару які відображені в його технічних характеристиках. ізрозумілі потенційному споживачу.

7) економія часу, уникнення бюрократизму та упередженості приотриманні послуги). 
Така модель формування інноваційної поведінки споживача щодо технічних інновацій та товарівзбільшують його можливості у подоланні стереотипів своєї поведінки та стимулюють роботу виробників та продавців у пошуку свого споживача.

Зберігаючи свої індивідуальні особливості. споживач може краще зробити свій вибір саме через залученнятехнічних інновацій. На його рішення помітновпливає його технічні можливості вчасно та цілісно отримати інформацію про споживчі властивості товарів, які він аналізує та вивчає перед прийняттям рішення про купівлю товару чи замовлення послуги. Водночас він активізує вплив виробників та продавців до активного пошуку нових виробничих таїх інновацій, якібудуть застосовуватись ними у майбутній діяльності для реалізації своїх проектів.

Висновки і перспективи подальших досліджень.Оновлення споживачем своєї поведінки щодо технічних інновацій розширює його готовність прийняти інновацію інших агентів ринкучим сприяє розвитку всіх сфер економіки, ведення бізнесу, управління розвитком та конкурентоспроможністю.

Отже,шляхами формування інноваційного споживання як інноваційної моделі сучасноїекономічної поведінки споживача $є$ :

1. Збільшення вимог споживача до властивостей та безпечності товарів що сприятиме збільшенню можливостей у конкурентоспроможних виробників тапродавців,збільшення рівня розповсюдження інновацій в економіці. Виробники, якіхочуть бути конкурентоспроможними на ринку все ширше можуть використовуватине тільки стратегії гнучкого ціноутворення, але й виділяти все більше ресурсів на врахування вимог споживачів у виробництві нових товарів.

2. Покращення іміджу виробника чи продавця що сприятиме тому, що його інноваційні товари будуть розглядатись споживачем на відповідність його інноваційним вимогам, а при виправданні довіри потенційних споживачів виробник розширить збут своєї продукції, чим забезпечить інноваційний розвиток та інноваційно-інвестиційні можливості.

3. Розповсюдження інноваційних товарівякі швидшезнаходять свого інноваційного споживача, якщо при виробництві цих товарів використовується нова ресурсозберігаюча, екобезпечна технологія.Цей вибір будехарактерний для всіх товарів, які планує купувати споживач 3 інноваційною поведінкою. Споживачі будуть вважати купівлю неприйнятною, якщо у них немає впевненості в тому, що технологія виробництва відповідає їх відповідальному споживанню і стане стандартною для виробника в подальшому.

4. Посилення координації учасників суспільного виробництва а саме їх діяльності у фазі виробництва, розподілу, обміну та споживання.Посилення координації збільшує інформаційний потік від виробників до споживачів. У результаті зростає доцільність, очікуваність, поширення та визнання ринкомінноваційного продукту. Врахуваннявимог інноваційного споживання доінновацій у зворотному порядку (від споживачів до виробників) споживачі-новатори можуть допомогти у визначенні вибору нових характеристик та властивостей товару.

5.3більшення вимогта актуалізаціївитрат на науково-дослідні та дослідно-конструкторські роботи виробників що позитивно впливає на розвиток їх інновацій, вдосконалення технологій і розвиток нових форм розповсюдження та збуту інноваційної продукції.

В умовах сучасного глобалізованого ринку інноваційне споживання як основна складова сучасної економічної поведінки споживачів визначає ситуацію на ринку. Саме споживачі, а не виробники ухвалюють рішення щодо придбання інновацій. Кожен споживач має свою особисту інноваційну мотиваціюпридбання товарів та послуг, своє бачення раціонального вибору, який грунтуєтьсяна критеріях ціни, якості, чим впливає на економічну поведінку виробників, шляхи ведення їх бізнесу,дотримання безпечності технології виробництва Інноваційне споживання своїм вибором поєднує особисту мету та мету економічного розвитку України.

\section{Джерела та література}

1. Зозульов О. Критерії ефективного ринкового позиціонування товарів на споживчомуринку //Маркетинг в Україні. - 2015. - № 2 (89). - С. 39-45.

2. Ілляшенко С. М. Маркетинг інновацій та інноваційний маркетинг, їх місце серед концепцій ведення бізнесу / С. М. Ілляшенко [Електронний ресурс]. - Режим доступу : http://elkniga.info/ book_144_gl_9_1.3_Marketing_innovaciji_ta.html 
3. Інноваційна практика польських підприємств [Електронний ресурс]. - Режимдоступу: http:// www.management.com.ua/cases/case017_3.html.

4. Котлер Ф. Латеральный маркетинг: технология поиска революционных идей /Филипп Котлер, Фернандо Триас де Бес; пер. с англ. - М. : Альпина паблишерэ,2010. - 206 с.

5. Портер М. Стратегія конкуренції / Портер М.;[пер. $з$ англ.]. - К.: Основи, 1998. - 390 с.

6. Соломон Майкл Р. Поведение потребителя. Искусство и наука побеждать на рынке : пер. с англ. /Майкл Р.Соломон. - Санкт-Петербург : ООО «Диа Софт ЮП», 2003. -784 с.

7. Функції інноваційного менеджменту - стратегічний маркетинг. URL: libsib.ru/innovatsionniymenedzhment/funktsii-innovatsionnogo- menedzhmenta / strategicheskiy-marketing (дата звернення: 16.07.2013).

8.Якушев А. Ж., Філін С. А. Інноваційна економіка і стандартизація // Економічний аналіз: теорія i практика. 2009. № 14. С. 32. Поведінка споживача інноваційної продукції

9. C. Anderson, James A. Narus, Woutervan Rossum. Customer Value Propositionsin BusinessMarkets-

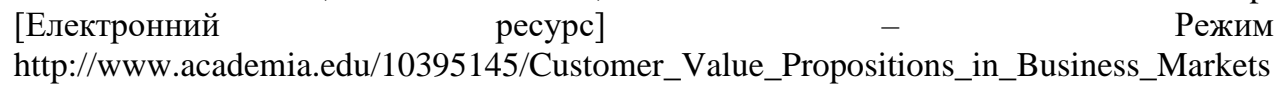

10. Carr N. Neuro marketing could make mind reading theadman's ultimate tool / NickСarr [Електронний pecypc]. - Режим доступу :http://www.guardiaii.co.uk/technology/2008/apr/03/news.advertisig

11. Creating a uniqueselling pro position - [Електронний ресурс] - Режим доступу:http://www.slideshare.net/mistykortes/creating-a-unique-selling-proposition

12. Marketing Strategy: What Makes You Special? - [Електронний ресурс] - Режимдоступу: https://www.b2binternational.com/publications/marketing-strategy-what-makesyou-special/

13. Rogers E.M., Shoemaker F.F. Communication of Innovations. A cross cultural approach. - 2nd ed. NewYork, FreePress, 1971.

\section{References}

1.Zozul'ov O. (2015). Kryteriyiefektyvnohorynkovohopozytsionuvannyatovarivnaspozhyvchomurynku [Criteria for the effective market positioning of goods in the consumer market]. Marketynh v Ukrayini - Marketing in Ukraine, № 2 (89), 39-45 [in Ukrainian].

2. Illyashenko S. M. Marketynhinnovatsiy ta innovatsiynyy marketynh, yikhmistseseredkontseptsiyvedennyabiznesu [Marketing of innovations and innovative marketing, their place among business concepts]. Retrieved from: http://elkniga.info/book_144_gl_9_1.3_Marketing_innovaciji_ta.html

3. Innovatsiynapraktykapol's'kykhpidpryyemstv [Innovative Practice of Polish Enterprises. Retrieved from: http:// www.management.com.ua/cases/case017_3.html.

4. Kotler P., Trias de Bes F. (2010). Lateral'nyymarketynh: tekhnolohyyapoyskarevolyutsyonnykhydey [Lateral marketing: the technology of the search for revolutionary ideas]. M.: Al'pynapablysheré, [Translation from Russian].

5. Porter M. (1998). Stratehiyakonkurentsiyi [Competition Strategy]. K.: Osnovy [Translation from English].

6. Solomon Michael R. (2003). Povedenyepotrebytelya. Yskusstvo y naukapobezhdat' narynke [Consumer Behavior. The Art and Science of Winning the Market] Sankt-Peterburh: OOO «DyaSoftYUP».

7. Funktsiyiinnovatsiynohomenedzhmentu - stratehichnyymarketynh. [Functions of the innovative management strategic marketing]. Retrieved from: libsib.ru/innovatsionniy-menedzhment/funktsii-innovatsionnogo- menedzhmenta / strategicheskiy-marketing

8. Yakushev A. Zh., Filin S. A. (2009).Innovatsiynaekonomikaistandartyzatsiya [Innovative economics and standardization]. Ekonomichnyyanaliz: teoriyaipraktyka - Economic analysis: theory and practice, 14, 32 [in Ukrainian].

9. Anderson C., James A. Narus, Wouter van Rossum. Customer Value Propositions in Business Markets. Retrieved from: http://www.academia.edu/10395145/Customer_Value_Propositions_in_Business_Markets

10. Carr N. (2008). Neuromarketing could make mind reading the adman's ultimate tool. Retrieved from: http://www.guardiaii.co.uk/technology/2008/apr/03/news.advertisig

11. Creating a unique selling proposition. Retrieved from: http://www.slideshare.net/mistykortes/creating-aunique-selling-proposition

12. Marketing Strategy: What Makes You Special? Retrieved from: https://www.b2binternational.com/publications/marketing-strategy-what-makesyou-special/

13. Rogers E.M., Shoemaker F.F. (1971). Communication of Innovations. A cross-cultural approach. (2nd ed.). New York, Free Press. 